ISSN 1991- 8690

website :http:// jsci.utq.edu.iq
الترقيم الدولي 8690 - 1991

Email: utjsci@utq.edu.iq

\title{
Study the Toll-like Receptor 2 and Dectin-1 in mice treated with beta-glucans and infected with Salmonella Typhimurium
}

\author{
Nidhal R. Mahdi ${ }^{1}$ \\ Kawakib I.M. Al-zubaidy ${ }^{2}$ \\ ${ }^{1}$ Department of Microbiology-Collage of Veterinary medicine - university of Baghdad. \\ ${ }^{2}$ Department Of Microbiology - Science Collage - University of Thi- Qar. \\ Correspondence to: Prof. Dr. Nidhal R. Mahdi \\ Email: dr.nidhalraoof @yahoo.com
}

\begin{abstract}
Objective: Toll-like receptors (TLRs) are essential components for the induction of innate immune responses in different tissues including the small intestine, spleen and mesenteric lymph nodes. We investigated the expression of TLR2 in these tissues in mice infected with Salmonella Typhimurium. In this study we have examined how dectin-1, a lectin family receptor for $\beta$-glucans, collaborates with TLR-2 in recognition of microbes.
\end{abstract}

Methods :In this study two groups of mice were treated with the $\beta$ - glucan (local and commercial extract) and infected with $\left(1 \times 10^{6} \mathrm{CFU} / \mathrm{ml}\right) S$. Typhimurium at different intervals group 1 at day zero and group 2 after seven days of the experiment .The immunohistochemistory assay has been performed to detect TLR-2 and dectine- 1 in the tissues of small intestine, spleen and mesenteric lymph nodes of the mice; the principle of this assay was done according to the manufacturer instructions (U.S.biological) .

Results: In the immunohistochemistory assay, positive cells were indicated by cytoplasmic staining and the percentage of positive in 100 cells was recorded and graded. The grades were $1+(<25 \%), 2+(25-75 \%)$ and $3+(>75 \%)$. Statistical analysis with Chi- Square tests revealed that there were significant differences $(\mathrm{p}<0.05)$ between groups, also between grades within the same group in the small intestine, spleen with TLR2 expression; also we demonstrated the same results with Dectin-1 expression in the small intestine and mesenteric lymph nodes, except in the spleen which showed that there were no any relevant differences $(p<$ 0.05 ) between the groups and the cell- grades within the group itself.

Conclusions: The Oral treatment of both soluble $\beta$-glucan from Saccharomyces cerevisiae (Local and commercial extracts) enhanced the host resistance in mice before the infection with S.Typhimurium. The results of Immunohistochemical assay showed that the $\beta$ - glucan also inducted the expression of Dectin- 1 and TLR-2 receptors on the cells, and also proved a collaborative reaction between these two receptors.

Key words: ß-glucan, Dectin-1, Toll-like receptor 2(TLR2), Immunohistochemical assay (IHC). 


\section{دراسة مستقبل Toll-Like receptor و Dectin-1 و في الفئران المعاملة بمركب البيتاكلوكان والمصابة Salmonella Typhimurium وبكتيريا}

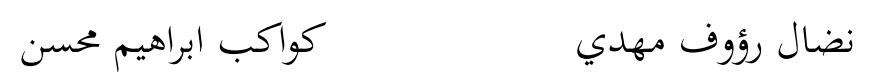

الخلاصة

الهاف: يعد مستقبل ( Toll - Like Receptor 2 من المكونات الضرورية لتحفيز ألأستجابة المناعية العفوية في أعضاء مختلفة

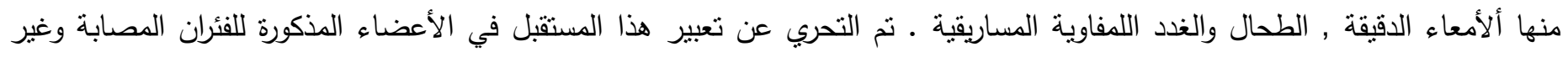

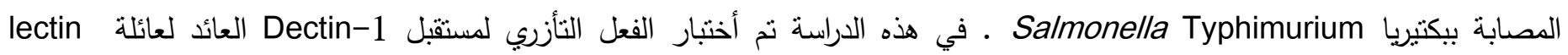

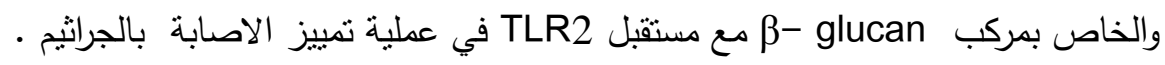

Salmonella المواد وطرق العمل: في هذة الدراسة عوملت الفئران بالمستخلص النجاري والمحلي لمركب البيتاكلوكان , أصييت ببكتريا

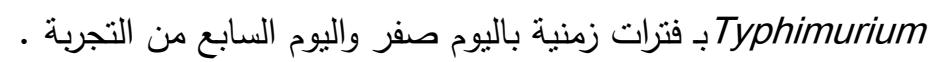

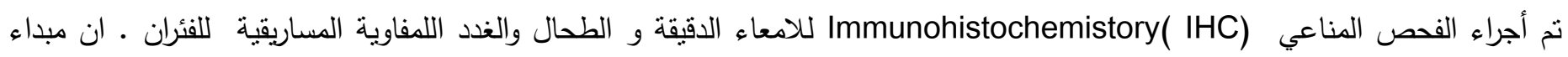
نظام التصبيغ هو وفقاء الى تعليمات الثركة المصنعة( (U.S.biological).

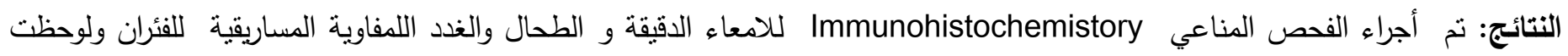

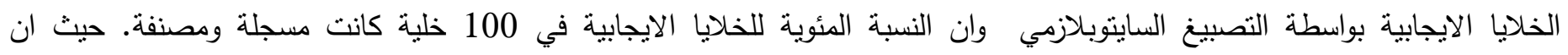

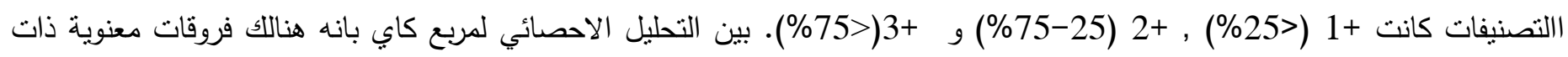

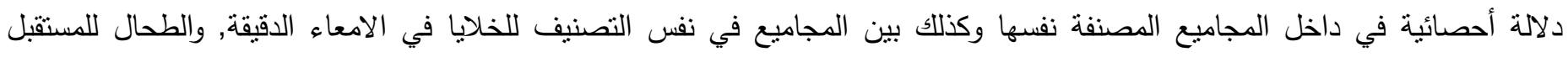

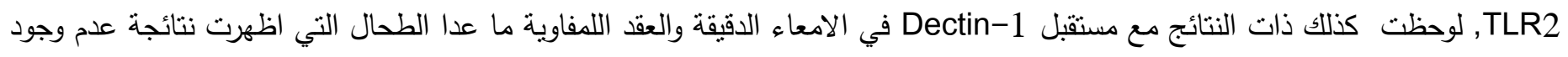
اي اختلافات ذات صلة بين المجاميع وتصانيف الخلايا في داخل الدجموعة نفسها.

الاستنتاجات: حفزت المعاملة عن طريق الفم للمستخلص الذائب للمركب التجاري والمحلي للبيتاكلوكان من خميرة Saccharomyces Cerevisiae مركب البيتاكلوكان يعمل على زياده تعبير مسنقبلات الـ Dectin-1 and TLR2 على الخلايا كما ويشجع التأثير الثأزري لهذين المستقبلين . 


\section{Introduction}

Beta glucan is a common term for a number of non-starch polysaccharides occurring in plants and microorganisms which contain glucose as the monomer, or building block. B-glucan is a safe and very potent biological response modifier that nutritionally activates the immune response through the Macrophages to yield various therapeutic effects (Vetvicka \& Novak, 2011). These polysaccharides are consisting of glucose residue jointed by beta linkage (Chen and Seviour 2007). They are found at a high levels in the cell wall of fungi, yeast, oat, barley, as well as bacteria (McIntosh et al., 2005). Their structures are diverse with fungal $\beta$-glucans being beta-1,3 linkage branched by 1,6 while oat and barley betaglucans linked by linear 1,3 and 1,4 bonds (Chen and Seviour 2007; Sadiq ,et al., 2008). $\beta-1,3 / 1,6-$ Glucans exert most of these effects by binding to specific receptors on macrophages, neutrophils, monocytes, dendritic cells, and natural killer cells , Dectin-1, a C-type lectin-like pattern-recognition receptor has been identified as the major $\beta$-glucan receptor. This receptor acts collaboratively with Toll-like receptor 2 (TLR2) for the induction of cytokines i.e., tumor necrosis factor alpha (TNF- $\alpha$ ) and interleukin-12 (IL-12) and other inflammatory mediators. Another less prominent receptor is complement receptor 3 (Reid, et al., 2004) .

A family of Toll-like receptors (TLR) was identified for humans and mice (Medzhitov, et al., 1997). TLR2 proteins are member of the Toll like receptor family, which play fundamental roles in pathogen recognition, and activation of innate immunity. They recognize pathogen associated molecular patterns (PAMPs) that are expressed on infectious agents, and mediate the production of cytokines necessary for the development of effective immunity ( Rindsjö, et al., 2007) .

Salmonella enterica has emerged during the last decades as an important public health problem in most developed countries. The main source of infection is consumption of animal products. There are over 2500 different serotypes of Salmonella (Popoff, et al., 2000). Most serotypes are potential human pathogens even though few serotypes are regularly associated with disease. Human infected with multi-resistant S.Typhimurium has been associated with consumption of beef, chicken, unpasteurized dairy products, and to a lesser extent, with infected animal contacts.

The aim of this study was to assess the expression of TLR2 and Dectin-1 on different immunological and epithelial cells in the small intestine, spleen and mesenteric lymph nodes as a response to $\beta$-glucan in mice infected and none infected with S.Typhimurium at different intervals.

\section{Materials and methods}

\section{1-Preparation of bacterial strain}

Salmonella Typhimurium strain, originating from the unit of zoonotic diseases of the College of Veterinary Medicine, Baghdad University, was used for inoculation. The frozen stock was subcultured in nutrient broth overnight at $35^{\circ} \mathrm{C}$. The bacterial count was determined by Miles and Misera method ; final count used was $1 \times 10^{6}$ $\mathrm{CFU} / \mathrm{ml}$.

\section{2- Preparation of $\beta$ - glucan}

Yeast derived $\beta$ - glucan was used (local and commercial extract). The local soluble $\beta$-glucan extract was prepared from Saccharomyces cerevisiae according to the method published by Williams et al . (1991), and the modified method by Chaung, et al (2009). Phenol-sulfuric acid method was carried out according to Dubois, etal. (1956) and modified by Masuko et al. (2005) in order to determine sugar content in the extract.

\section{3- Animals and Experimental Design}

One hundred sixty of the mice-males aged 6-7 weeks and were purchased from (Animal house colony of National Center for Drug Control and Research), housed in individually in standard cages in an environmentally controlled. Room temperature was maintained at $21 \pm 3{ }^{\circ} \mathrm{C}$, the air of the room was changed continuously by using ventilation vacuum .The litter of the cages was changed every day. The animals hosted in animal house of College of Veterinary Medicine, Baghdad University, and were fed on pellet. 
The (160) mice- males were divided into three groups; and the $0.2 \mathrm{~mL}\left(1 \times 10^{6} \mathrm{CFU}\right)$ of $S$. Typhimurium was used as $\mathrm{LD}_{50}$ dose according to the pilot study.

Group 1(G1): Treated with the local soluble $\beta$ glucan extract (LE): divided into two groups : G1a: infected with Salmonella Typhimurium at day 0 .

G1b: infected with Salmonella Typhimurium at day 7.

Group 2(G2): Treated with the commercial $\beta$ glucan extract (CE): divided into two groups: G2a: infected with Salmonella Typhimurium at day 0 .

G2b: infected with Salmonella Typhimurium at day 7.

Group 3 (G3): control groups which included four groups:

G3a: without $\beta$ - glucan treatment and not infected with S.Typhimurium .

G3b: infected with S.Typhimurium only.

G3c: treated with LE only.

G3d: treated with CE only .

Three mice were scarified from each group at day $(0,2,4,8,12,14)$, Samples were taken from small intestine, spleen, mesenteric lymph nodes for the immunohistochemical study of expression the Dectin -1 and TLR2.

\section{4- Immunohistochemistory assay}

The immunohistochemical procedure was done according to the manufacturing company's standards and guidelines. All tissues were fixed in $10 \%$ formalin and embedded in paraffin. A representative block for each case was selected and $3 \mu \mathrm{m}$ thick sections were made for immunohistochemistry using the standard labeled streptavidin -biotin method. Deparaffinised sections were placed in a pressure cooker for antigen retrieval using citrate buffer $\mathrm{pH} 6$ for 10 minutes. These were then incubated at room temperature and washed with distilled water. After washing, the sections were placed in hydrogen peroxide 3\% for 6 minutes to block endogenous peroxide, then the sections were washed with water three times and finally washed by Tris-buffered saline (TBS) for 10 minutes to eliminate non- specific staining. The excess TBS was removed from the slides before incubation with primary antibody. The sections were incubated with the primary antibodies (TLR2 [1:250] and Dectin - 1 [1:250]) for 30 minutes at room temperature. The sections were washed with TBS and incubated with link antibody for 15 minutes each. Then the section were washed with TBS and incubated with labeled Streptavidin-biotin (LSAB) for 15 minutes at room temperature. The sections were again washed with TBS and incubated with diaminobenzidine (DAB) and substrate chromogen system, for 5 minutes at room temperature which resulted in brown colored precipitates at the antigen site. The sections were then counterstained with haematoxylin for 1 minute and were mounted. The expression of TLR2 and Dectin receptors were measured as the same scoring system (Quick scoring) used by Abdul Rahman, et al., (2010). The positivity of cells for expression of these receptors seen as brown staining. It was graded as four grads:

Score 0 equal to $<10 \%$ positive cells.

Score $1+$ equal to $10-25 \%$ positive cells.

Score $2+$ equal to $25-75 \%$ positive cells.

Score $3+$ equal to $75-100 \%$ positive cells.

\section{Results and discussion}

\section{Extraction of local $\beta$ - glucan (LE)}

According to the Hunter et al., (2004), each 0.45 $\mathrm{kg}$ of the Saccharomyces cerevisiae, yields 14.05 gm of the crude particulate $\beta$ - glucan, which show as fine bright white powder after lyophilized, then according to William (1991), local extraction of insoluble $\beta$-glucan with $70 \%$ phosphate was getting, and the total concentration of carbohydrates present in the extract was determined according to the method used by Dubois et al (1956), and modified by (Masuko et al. 2005); the value was $25 \mathrm{mg} / \mathrm{ml}$.

\section{Bacterial identification}

Salmonella organisms first recognized in smears stained with Gram stain, which appeared as Gram negative, rod, usually motile with 
peritrichous flagella (Jawetz et al., 2007). Pure colonies were obtained and separate through the culture, and growing on different media, on blood agar medium it appeared as small rounded white to grayish, non hemolytic colonies. The growing colonies on the MacConky agar were lactose-non fermenter so it appeared as yellowish in color. On the SS agar, which was the most commonly selective media used for Salmonella, colonies appeared as small rounded with black center. Subsequent routine bacteriological examination has been carried out for identify the species of Salmonella, include the most important biochemicals tests as Api 20 E System. The results of API-20E system showed that all isolates were gram negative bacteria and gave the same results to the routinely biochemical tests (Leboffe and Piercr, 2005).

\section{Determine the CFU/ ml for bacterial growth}

To determine the number of colony forming units in a bacterial suspension according to Miles $\&$ Misers (1938), Populations were then serially diluted and incubated in broth culture ( Brain heart infusion broth). To confirm Salmonella growth, $1000 \mu \mathrm{l}$ from each culture tube was placed on to MacConkey agar and was incubated overnight at $37^{\circ} \mathrm{C}$. Bacterial counts were then calculated based on the last dilution at which growth was detected as follow :

CFU per $\mathrm{ml}=$ Average number of colonies for a dilution $\mathrm{x} 50 \mathrm{x}$ dilution factor.

CFU per $\mathrm{ml}=24 \times 50 \times 10^{-6}$

$\mathrm{CFU}$ per $\mathrm{ml}=3 \times 50 \times 10^{-7}$

CFU per $\mathrm{ml}=1 \times 50 \times 10^{-8}$

Results of the pilot study in determination of the $\mathrm{LD}_{50}$ of the Salmonella Typhimurium; showed the development of lethality occurred in the group of mice that orally inoculated with $1 \times 10^{6}$ CFU (Hung, etal. 2011).

\section{Expression of the Toll - Like Receptor and Dectin-1}

The results of the immunohistochemical analysis demonstrated positive staining for TLR2 and Dectin-1 in the control positive and group which is treated with $\mathrm{CE}$ and with LE in the different parts of the small intestine( figure $-1 \mathrm{a}$; figure-1b) , spleen (figure-2 a; figure-2b) and mesenteric lymph nodes( figure -3 ). Both treated groups ( $\mathrm{CE}$ and $\mathrm{LE}$ ) have given good immune responses but the results showed that treated group with $\mathrm{CE}$ is better than the LE in case of expression of the Toll-like Receptor and Dectin-1.

The Statistical analysis with Chi- Square tests have revealed that there were a significant differences $(p<0.05)$ between the groups within the grades itself and also between the grades within the same group in the small intestine (Table -1a; Table -1b), spleen (Table -2a) and mesenteric lymph nodes (Table-3). There was no any relevant significant differences between the groups within the grades in the spleen (table $-2 b$ ).

The expression of TLR2 and Dectin-1 receptors were measured as the same scoring system (Quick scoring) used by Abdul Rahman, et al., (2010). The positivity of cells for expression of these receptors seen as brown staining.

Reid et al., (2004) Willment et al.,(2005), they identifying Dectin-1 as the major receptor for fungal $\beta$-glucans on murine macrophages. They demonstrated that Dectin-1 is widely expressed on all monocyte / macrophages, DC, neutrophils and eosinophils populations as well as on B cells and a subpopulation of T cells.

Adachi et al.(2004) provided an suitable characterization of $\beta$-glucan recognition site on Dectin-1. In their study, they tried to deduce the amino acid residues in dectin-1 responsible for $\beta$ glucan recognition.

The results confirmed with results of Benjamin, et al.,(2003) who identified that dectin-1 is an important partner for TLR2 on macrophages and dendritic cells for the production of inflammatory cytokines in response to particulate stimuli containing $\beta$-glucans. Collaboration between dectin-1 and TLR2 in orchestrating immune responses provides a valuable model for elucidating the mechanisms of interaction between multiple innate immune recognition receptors during microbial recognition. 
The results established according to the significant role for dectin-1, in cooperation with TLR2 to activate a macrophage's pre-inflammatory response to a S.Typhimurium infection (Yadav and Schorey, 2006). It was also in agreement with the study by (Cario, 2008) in which he provided first evidence of TLR2-mediated control of mucosal inflammation via directly enhances intestinal epithelial barrier function.

Typical to the TLR stimulation is the production of proinflammatory mediators such a TNF- $\alpha, \mathrm{IL}-1 \beta$, and IL-6. These cytokines play a role in pathogen clearance by stimulating phagocytosis and superoxide production in macrophages, stimulating differentiation and maturation of $\mathrm{B}$ cells and $\mathrm{T}$ cells, and acting as a chemoattractant and activator for cells such as neutrophils. In addition, TLR stimulation can lead to the production and release of chemokines, such as CXCL8 (IL-8), these chemokines act by augmenting neutrophil adhesion, degranulation, and antimicrobial activity (Parker, et al., 2007).

Table (1a): The expression of TLR2 in small intestinal tissue cells in mice:

\begin{tabular}{|c|c|c|c|c|c|c|c|}
\hline \multicolumn{2}{|c|}{ Grades } & \multicolumn{2}{|c|}{+1} & \multicolumn{2}{|c|}{+2} & \multicolumn{2}{|c|}{+3} \\
\hline \multicolumn{2}{|c|}{ G. Tissue } & Mice No. & $\begin{array}{c}\text { \% within each } \\
\text { group }\end{array}$ & Mice No. & $\begin{array}{c}\text { \% within } \\
\text { each group }\end{array}$ & Mice No. & $\begin{array}{c}\text { \% within each } \\
\text { group }\end{array}$ \\
\hline \multirow{3}{*}{ G1a } & D & 6 & 30 & 7 & 35 & 7 & 25 \\
\hline & $\mathbf{J}$ & 5 & 25 & 7 & 35 & 8 & 35 \\
\hline & I & 5 & 25 & 7 & 35 & 8 & 35 \\
\hline \multirow{3}{*}{ G1b } & D & 8 & 40 & 5 & 25 & 7 & 25 \\
\hline & $\mathbf{J}$ & 8 & 40 & 7 & 35 & 5 & 35 \\
\hline & I & 8 & 40 & 5 & 25 & 7 & 25 \\
\hline \multirow{3}{*}{ G2a } & D & 8 & 40 & 5 & 25 & 7 & 25 \\
\hline & $\mathbf{J}$ & 7 & 35 & 7 & 35 & 6 & 35 \\
\hline & $\mathbf{I}$ & 8 & 40 & 6 & 30 & 6 & 30 \\
\hline \multirow{3}{*}{ G2b } & D & 7 & 35 & 6 & 30 & 7 & 30 \\
\hline & $\mathbf{J}$ & 7 & 35 & 6 & 30 & 7 & 30 \\
\hline & I & 7 & 35 & 6 & 30 & 7 & 30 \\
\hline \multirow{3}{*}{ G3a } & D & - & 0 & - & 0 & $=$ & 0 \\
\hline & $\mathbf{J}$ & - & 0 & - & 0 & - & 0 \\
\hline & $\mathbf{I}$ & - & 0 & - & 0 & - & 0 \\
\hline \multirow{3}{*}{ G3b } & D & 9 & 45 & 5 & 25 & 6 & 25 \\
\hline & $\mathbf{J}$ & 6 & 30 & 6 & 30 & 8 & 30 \\
\hline & $\mathbf{I}$ & 6 & 30 & 8 & 40 & 6 & 40 \\
\hline \multirow{3}{*}{ G3c } & D & 9 & 45 & 5 & 25 & 6 & 25 \\
\hline & $\mathbf{J}$ & 8 & 40 & 5 & 25 & 7 & 25 \\
\hline & I & 7 & 35 & 6 & 30 & 7 & 30 \\
\hline \multirow{3}{*}{ G3d } & D & 6 & 30 & 7 & 35 & 7 & 35 \\
\hline & $\mathbf{J}$ & 6 & 30 & 6 & 30 & 8 & 30 \\
\hline & $\mathbf{I}$ & 5 & 25 & 7 & 35 & 8 & 35 \\
\hline
\end{tabular}

$\mathbf{X}^{\mathbf{2}}=\mathbf{6 0 0 . 2} /$ Results showed that there were significant differences $(\mathrm{p}<0.05)$ between groups within the grades, also between grades within the same group as above in $\mathrm{G} 1 \mathrm{~b}(\mathrm{Grade}+1), \mathrm{G} 2 \mathrm{a}(\mathrm{Grade}+3), \mathrm{G} 2 \mathrm{~b}(\mathrm{Grade}+1)$, G3a(Grade +1), G3b(Grade +1+3), G3c(Grade +2 +3), G3d(Grade +1) .D.=duodenum ; J.=jejunum ; I. ileum . 
Table (1b): The expression of Dectin-1 in small intestinal tissue in mice:

\begin{tabular}{|c|c|c|c|c|c|c|c|}
\hline \multicolumn{2}{|c|}{ Grades } & \multicolumn{2}{|c|}{+1} & \multicolumn{2}{|c|}{+2} & \multicolumn{2}{|c|}{+3} \\
\hline \multicolumn{2}{|c|}{ G. Tissue } & Mice No. & $\begin{array}{c}\% \text { within } \\
\text { each group }\end{array}$ & Mice No. & $\begin{array}{c}\text { \% within } \\
\text { each group }\end{array}$ & Mice No. & $\begin{array}{c}\text { \% within each } \\
\text { group }\end{array}$ \\
\hline \multirow{3}{*}{ G1a } & D & 10 & 50 & 5 & 25 & 5 & 25 \\
\hline & $\mathbf{J}$ & 6 & 30 & 8 & 40 & 6 & 30 \\
\hline & $\mathbf{I}$ & 5 & 25 & 8 & 40 & 7 & 35 \\
\hline \multirow{3}{*}{ G1b } & D & 7 & 35 & 6 & 30 & 6 & 30 \\
\hline & $\mathbf{J}$ & 8 & 40 & 7 & 35 & 7 & 35 \\
\hline & $\mathbf{I}$ & 8 & 40 & 6 & 30 & 6 & 30 \\
\hline \multirow{3}{*}{ G2a } & D & 10 & 50 & 5 & 25 & 6 & 25 \\
\hline & $\mathbf{J}$ & 6 & 30 & 6 & 30 & 5 & 25 \\
\hline & I & 9 & 45 & 6 & 30 & 5 & 30 \\
\hline \multirow{3}{*}{ G2b } & D & 5 & 25 & 10 & 50 & 6 & 25 \\
\hline & $\mathbf{J}$ & 6 & 30 & 9 & 45 & 5 & 25 \\
\hline & I & 7 & 35 & 7 & 35 & 6 & 30 \\
\hline \multirow{3}{*}{ G3a } & D & - & $\mathbf{0}$ & - & 0 & - & $\mathbf{0}$ \\
\hline & $\mathbf{J}$ & - & $\mathbf{0}$ & - & $\mathbf{0}$ & - & $\mathbf{0}$ \\
\hline & I & - & $\mathbf{0}$ & - & $\mathbf{0}$ & - & $\mathbf{0}$ \\
\hline \multirow{3}{*}{ G3b } & D & 6 & 30 & 5 & 25 & 9 & 45 \\
\hline & $\mathbf{J}$ & 6 & 30 & 8 & 40 & 6 & 30 \\
\hline & I & 4 & 20 & 8 & 40 & 8 & 40 \\
\hline \multirow{3}{*}{ G3c } & D & 8 & 40 & 5 & 25 & 7 & 35 \\
\hline & $\mathbf{J}$ & 6 & 30 & 8 & 40 & 5 & 30 \\
\hline & I & 6 & 30 & 7 & 35 & 5 & 35 \\
\hline \multirow{3}{*}{ G3d } & D & 11 & 55 & 4 & 20 & 5 & 25 \\
\hline & $\mathbf{J}$ & 9 & 45 & 6 & 30 & 5 & 50 \\
\hline & I & 7 & 35 & 7 & 35 & 6 & 30 \\
\hline
\end{tabular}

$\mathbf{X}^{\mathbf{2}}=\mathbf{5 3 4 . 6}$ : Results showed that there were significant differences $(\mathrm{p}<0.05)$ between groups within the grades , also between grades within the same group as above in G1b(Grade +3$)$, G2a(Grade +1$)$, G2b(Grade +1$)$, G3a(Grade +1), G3b(Grade +1+2), G3c(Grade +1 +2), G3d(Grade +1) . 
Table (2a): The expression of TLR-2 in the spleen tissue in mice:

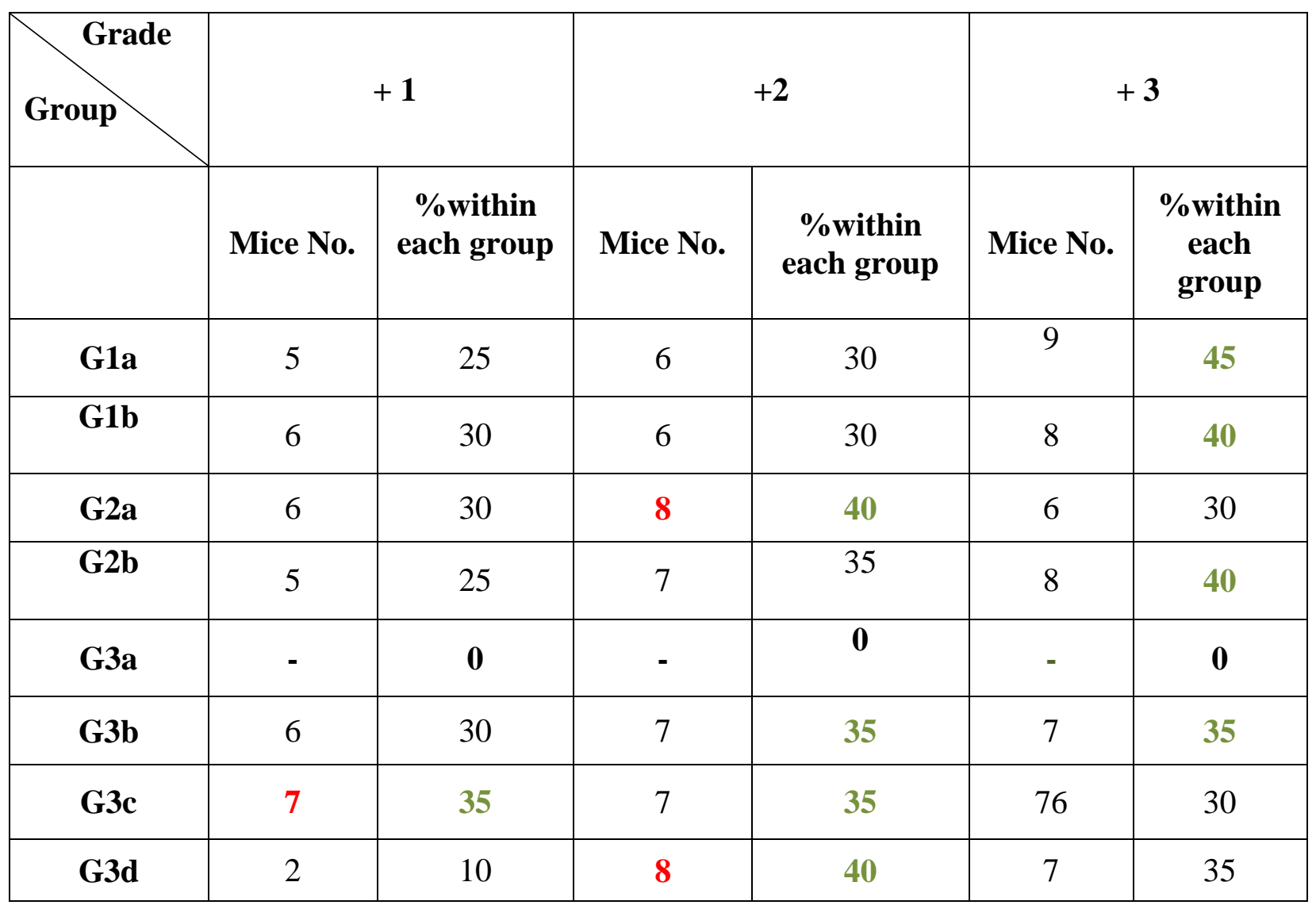

$X^{2}=26.549$

Results showed that there were a significant differences $(\mathrm{p}<0.05)$ between groups within the grades, also between grades within the same group as above in $\mathrm{G} 1 \mathrm{~b}(\mathrm{Grade}+2+3), \mathrm{G} 2 \mathrm{a}(\mathrm{Grade}+2), \mathrm{G} 2 \mathrm{~b}(\mathrm{Grade}+1,+2)$, G3a(Grade +2), G3b(Grade +3), G3c(Grade +3), G3d(Grade +3). 
Table (2b): The expression of Dectin-1 in the spleen tissue in mice :

\begin{tabular}{|c|c|c|c|c|c|c|}
\hline & \multicolumn{2}{|c|}{+1} & \multicolumn{2}{|c|}{+2} & \multicolumn{2}{|c|}{+3} \\
\hline & Mice No. & $\begin{array}{c}\text { \% within } \\
\text { each group }\end{array}$ & Mice No. & $\begin{array}{c}\% \text { within } \\
\text { each group }\end{array}$ & Mice No. & $\begin{array}{c}\% \text { within } \\
\text { each group }\end{array}$ \\
\hline G1a & 5 & 30 & 7 & 35 & 7 & 35 \\
\hline G1b & 7 & 35 & 6 & 30 & 7 & 35 \\
\hline G2a & 8 & 40 & 5 & 25 & 7 & 35 \\
\hline G2b & 6 & 30 & 7 & 35 & 7 & 35 \\
\hline G3a & - & $\mathbf{0}$ & - & $\mathbf{0}$ & - & $\mathbf{0}$ \\
\hline G3b & 8 & 40 & 4 & 20 & 8 & 40 \\
\hline G3c & 7 & 35 & 7 & 35 & 6 & 30 \\
\hline G3d & 8 & 40 & 5 & 25 & 7 & 35 \\
\hline
\end{tabular}

$X^{2}=23.451$ :

Results showed that there were no any relevant differences $(\mathrm{p}<0.05)$ between the groups and the cell- grades within the group itself. 
Table (3): The expression of Dectin-1 in the mesenteric lymph nodes tissue in mice

\begin{tabular}{|c|c|c|c|c|c|c|}
\hline $\begin{array}{c}\text { Grade } \\
\text { Group }\end{array}$ & \multicolumn{2}{|c|}{+1} & \multicolumn{2}{c|}{+3} \\
\hline & Mice No. & $\begin{array}{c}\text { \% within } \\
\text { each group }\end{array}$ & Mice No. & $\begin{array}{c}\text { \% within } \\
\text { each group }\end{array}$ & Mice No. & $\begin{array}{c}\text { \% within } \\
\text { each group }\end{array}$ \\
\hline G1a & 5 & 25 & 8 & 40 & 7 & 35 \\
\hline G1b & 6 & 30 & 7 & 35 & 7 & 35 \\
\hline G2a & 8 & 40 & 6 & 30 & 6 & 30 \\
\hline G2b & 6 & 30 & 8 & 40 & 6 & 30 \\
\hline G3a & - & 0 & - & 0 & - & 0 \\
\hline G3b & 3 & 15 & 7 & 35 & 10 & 50 \\
\hline G3c & 6 & 30 & 7 & 35 & 7 & 35 \\
\hline G3d & 8 & 40 & 6 & 30 & 6 & 30 \\
\hline
\end{tabular}

$X^{2}=\mathbf{2 5 . 4 6 4}$

Results showed that there were a significant differences $(\mathrm{p}<0.05)$ between groups within the grades , also between grades within the same group, as above in G1b(Grade +3), G2a\&G3a (Grade +1), G2b(Grade $+1,+2)$, G3b\&G3c $($ Grade +2$),$, G3d(Grade $+2,+3)$. 


\section{J.Thi-Qar Sci.}
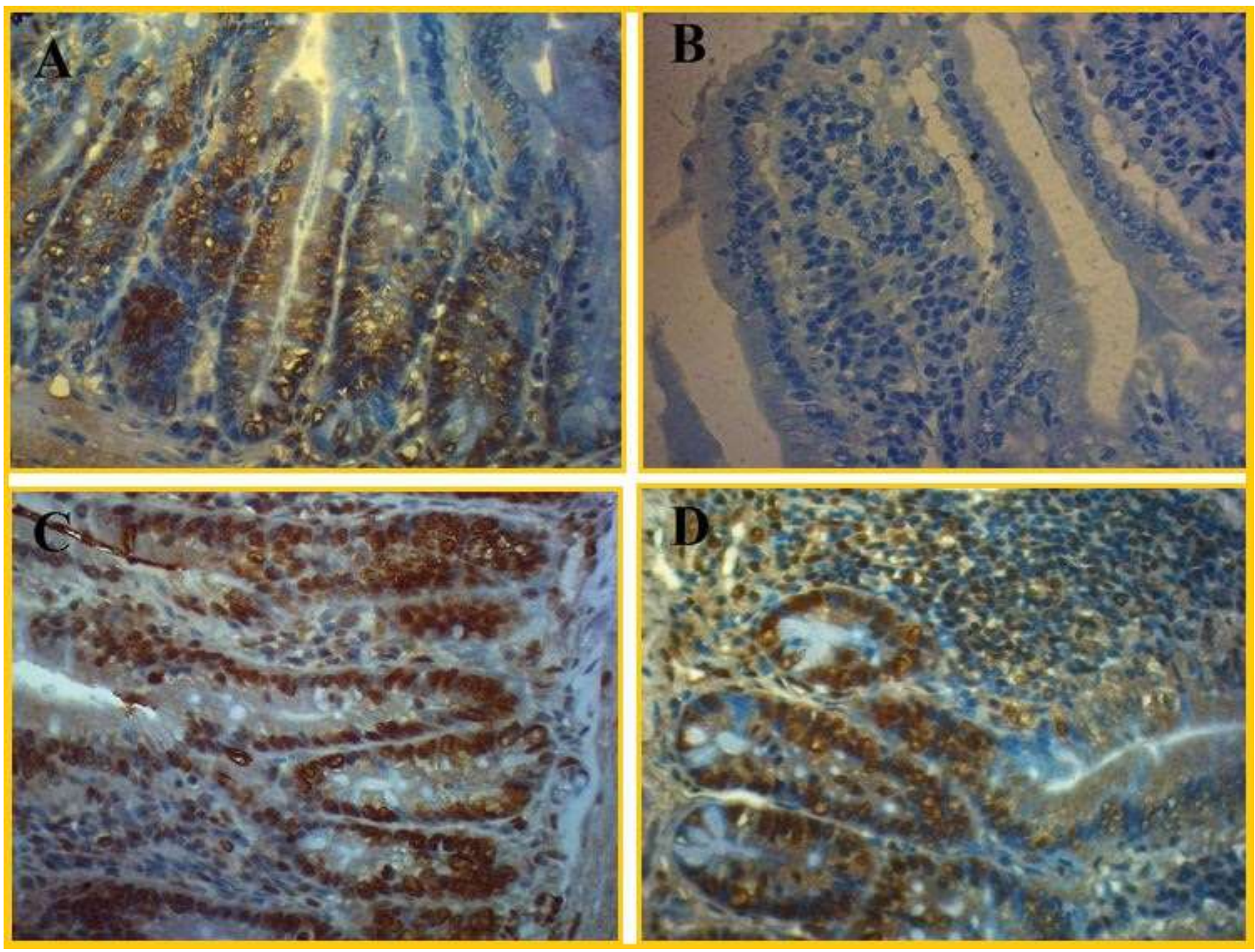

Figure (1a):IHC staining for TLR2 in the small intestine (Ileum,$\times 100$ ), specific staining of phagocytic \& epithelial cells with DAB chromogen (brown) and counterstained with Hematoxylin (blue). A, positive control; B, negative control; C, treated with C.E.\& D, treated with L.E 


\section{J.Thi-Qar Sci.}
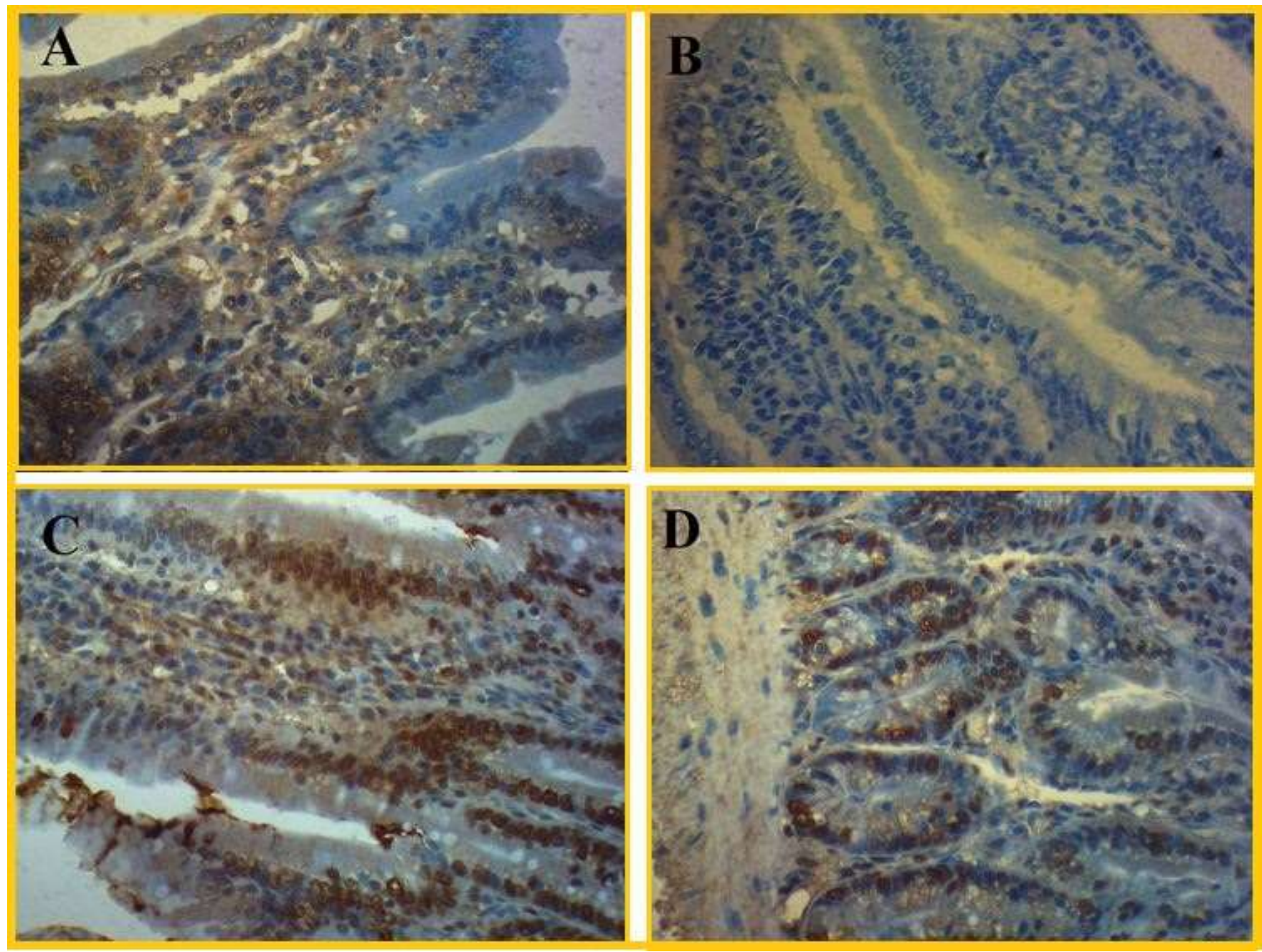

Figure (1b): Immunohistochemical staining (IHC) staining for Dectin-1 in the small intestine (Ileum,$\times 100)$, specific staining of phagocytic \& epithelial cells with DAB chromogen (brown) and counterstained with Hematoxylin (blue). A, positive control; B, negative control; C, treated with C.E. \& D, treated with L.E. 

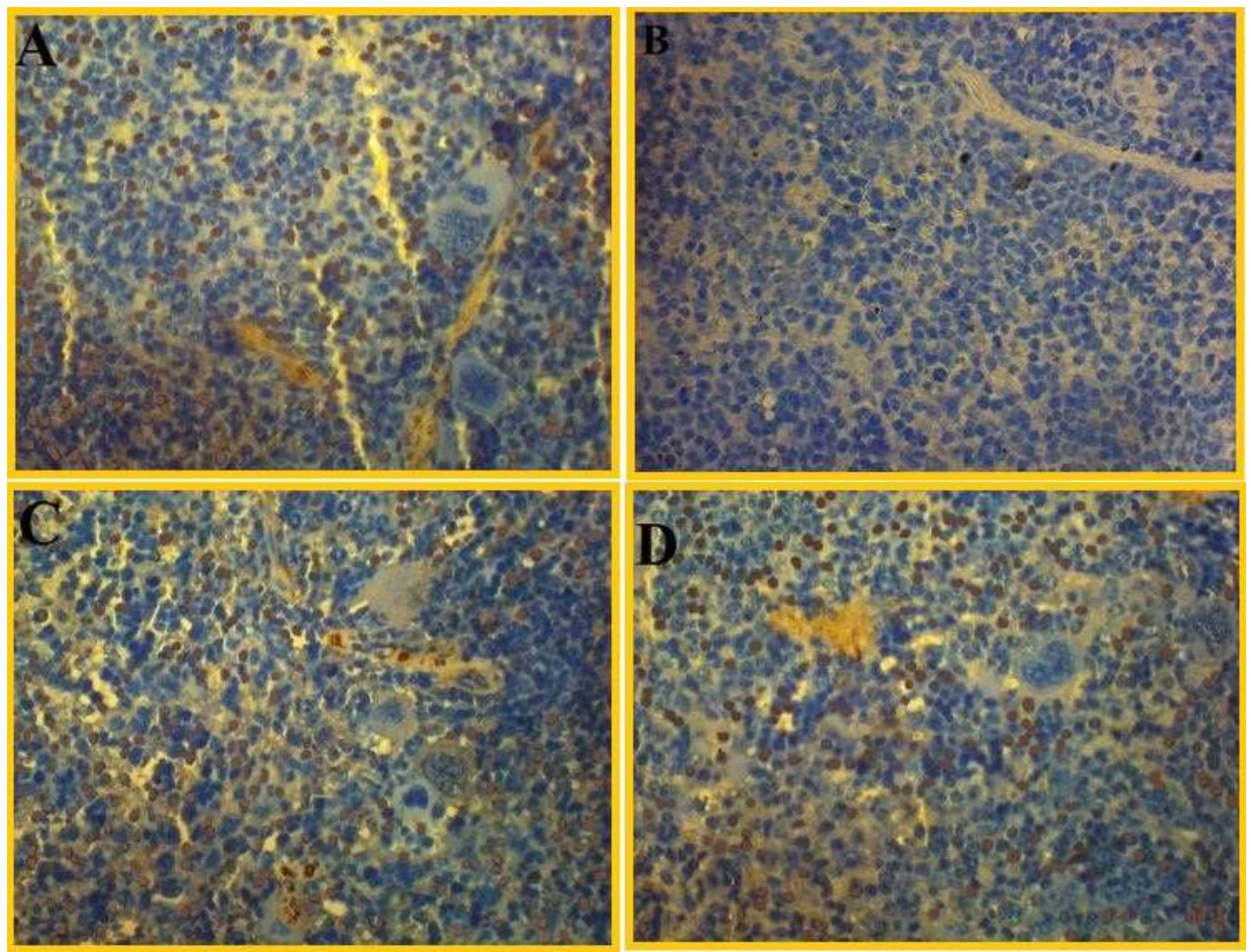

Figure (2a) IHC staining for TLR-2 in the Spleen $(\times 100)$, specific staining of phagocytic \& epithelial cells with DAB chromogen (brown) and counterstained with Hematoxylin (blue). A, positive control ; B, negative control ; C, treated with C.E. \& D, treated with L.E. 

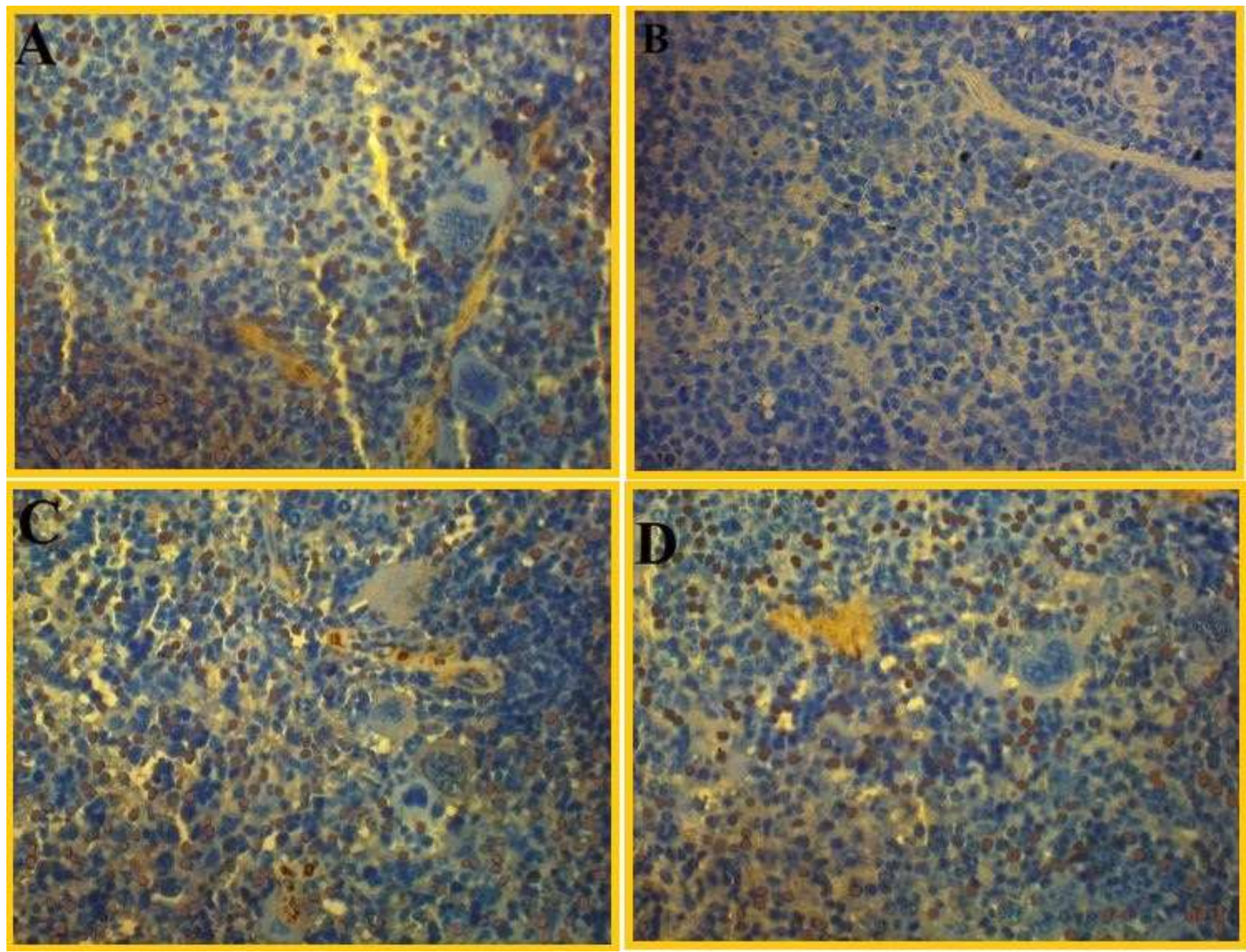

Figure (2b) IHC staining for Dectin-1 in the Spleen $(\times 100)$, specific staining of phagocytic \& epithelial cells with DAB chromogen (brown) and counterstained with Hematoxylin (blue). A, positive control; B, negative control; C, treated with C.E. ; D, treated with L.E. 


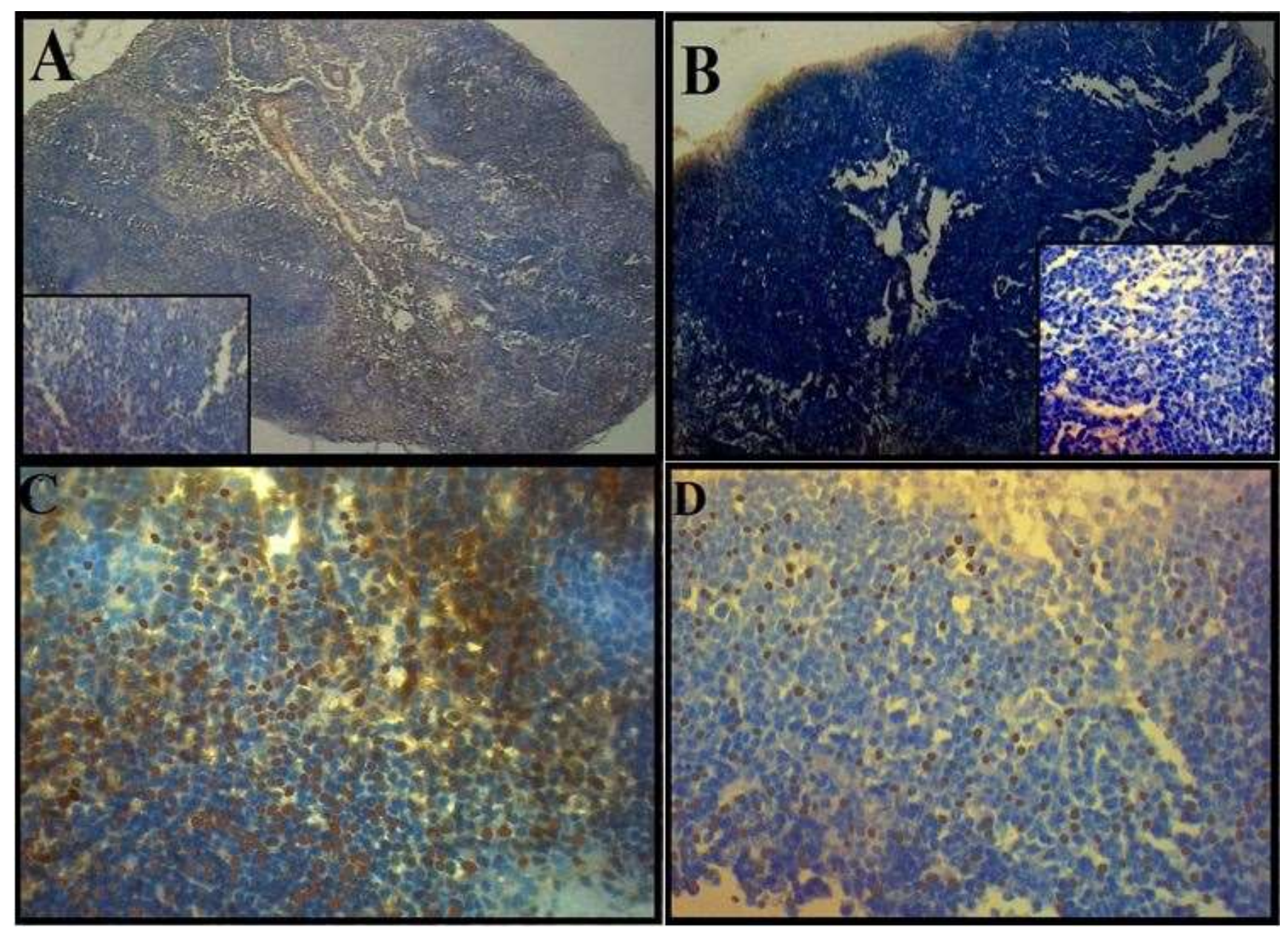

Figure (3): IHC staining for Dectin-1 of the Mesenteric Lymph nodes $(\times 100)$, specific staining of phagocytic \& epithelial cells with DAB chromogen (brown) and counterstained with Hematoxylin (blue). A, positive control; B, negative control; C, treated with C.E. \& D, treated with L.E.

\section{References:}

1-Benjamin, N.G. ; Randi, M.S.; Scott , J.C .; Shizuo ,A. and David,M.U.(2003).

Collaborative induction of inflammatory resposes by Dectin-1 and Toll - like Receptor 2.

2-Brown, G. D., Gordon, S. (2001) A new receptor for $\beta$-glucans. Nature 413, 36-37.
3-Brown, G. D., Herre, J., Williams, D. L., Willment, J. A., Marshall, A. S.and Gordon, S. (2003) Dectin-1 mediates the biological effects of -glucans. J.Exp. Med. 197, 1119-1124.

4- Cario ,E. (2008) . Barrier-protective function of intestinal epithelial Toll-like receptor 2 . Mucosal Immunology 1 (Suppl 1), S62S66. 
5-E, Holmlund U, Sverremark-Ekström E, Papadogiannakis $\mathrm{N}$ and Scheynius A(2007). Toll-like receptor-2 expression in normal and pathologic human placenta. Hum Pathol;38(3):468-73.

6- Sylvie Côté, A. ; Letellier, L. L. , and Sylvain Quessy (2004) . Distribution of Salmonella in tissues following natural and experimental infection in pigs . Can J Vet Res. 68(4): 241-248.

7-_Popoff MY, Bockemühl J, Brenner FW and Gheesling LL(2000). Supplement to the Kauffmann-White scheme. Res Microbiol ;152:907-909.

8- Underhill, D.M., and A. Ozinsky( 2002). Tolllike receptors: key mediators of microbe detection. Curr. Opin. Immunol. 14:103110.

9- Janeway, C.A., Jr., and R. Medzhitov( 2002). Innate immune recognition. Annu. Rev. Immunol. 20:197-216.

10- Williams, D.L., McNamee, R.B., Jones, E.L., Pretus, H.A., Ensley, H.E., Browder, I.W. and Di Luzio, N.R.(1991). A method for the solubilizationof a (1!3)-beta-D-glucan isolated from Saccharomyces cerevisiae. Carbohydr. Res. 219, 203-213.

11- Chaung, H.C., Huang,T.C., Yu,J.H., Wu,M.L. and Chung, W.B.( 2009). Immunomodulatory effects of b-glucans on porcine alveolar macrophages and bone marrow haematopoietic cell-derived dendritic cells. Veterinary Immunology and Immunopathology 131,147-157.

12- Dubois, M., Gilles, K. A., Hamilton, J. K., Rebers, P. A., and Smith, F.( 1956). Colorimetric method for determination of sugars and related substances. Anal. Chem. 28:350-356.
13-Masuko, T., A. Minami, N. Iwasaki, T. Majima, S. Nishimaru and Y.C. Lee, (2005). Carbohydrate analysis by a phenol-sulfuric acid method in microplate format. Anal. Biochem., 339: 69-72.

14- Chen, J. and Seviour, R.( 2007). Medicinal importance of fungal beta-(1-->3), (1-->6) glucans . Mycol. Res. 111(Pt 6):635-52.

15- Sadiq, B. M; Tahir-Nadeem, M. and Khan , MK.( 2008). Oat: unique among the cereals. Eur J Nutr.;47:68-79.

16- Reid, D. M., M. Montoya, P. R. Taylor, P. Borrow, S. Gordon, G. D. Brown, and S. Y. Wong. (2004). Expression of the betaglucan receptor, dectin-1, on murine leukocytes in situ correlates with its function in pathogen recognition and reveals potential roles in leukocyte interactions. J. Leukoc. Biol. 76:86-94.

17- Rindsjö E; Holmlund U; Sverremark-Ekström ;E, Papadogiannakis, N. and Scheynius, A (2007) .Toll-like receptor-2 expression in normal and pathologic human placenta. Hum Pathol;38(3):468-73.

18- Abdul Rahman, H .; Abdulwakil, E. M. and Geok , C. T.(2010). An immunohistochemical study of Toll-like receptors 2 and 4 in placenta with and without infection. Malaysian .J. Pathol. 2010; 32(1) : $13-19$.

19- Hunter ,K. W. ,Gault, R. A., Berner, M. D. (2004) Preparation of micropartical Bglucan from $\mathrm{S}$. cerevisiae for use in immune potentiation, Letters in Applied Microbiology ., 35 (4) :268 .

20- Jawetz, E.; Melink, J.L.; Steven, A. and Adelberg, E.A. (2007). Review of Medical Microbiology Textbook. $24^{\text {th }}$ Ed. International edition. McGraw-Hill Pub. 
21- Leboffe, M. J. and Piercr, B.E.(2005). Aphotographic Atlas for the "Microbiology Laboratory". $3^{\text {rd }}$ Ed.Chapter 6,Douglas N.Morton.U.S.A., 45-46.

22-_Popoff MY, Bockemühl J, Brenner FW, Gheesling LL. (2000) .Supplement to the Kauffmann-White scheme. Res Microbiol. 152:907-909.

23- Medzhitov, R., P. Preston-Hurlburt, and C. A. Janeway, Jr. (1997). A human homologue of the Drosophila Toll protein signals activation of adaptive immunity. Nature 388:394-397.

24-Miles, AA .; Misra, SS.and Irwin, JO (1938). "The estimation of the bactericidal power of the blood.". The Journal of hygiene 38 (6): $\quad 732-49 . \quad$ PMC 2199673. $\underline{\text { PMID }} \underline{20475467 .}$.

25-Hung-Jen , T.; Wen-Chien , K. ; Chi-Chung, C.; Po-Lin , C. and etal.(2011). In Vitro and In Vivo Intracellular Killing Effects of Tigecycline against Clinical Nontyphoid Salmonella Isolates Using Ceftriaxone as a Comparator. Antimicrob. Agents Chemother. 2011 June; 55(6): 2755-2759.

26- Willment, J.A., et al. (2005). The human betaglucan receptor is widely expressed and functionally equivalent to murine Dectin-1 on primary cells. Eur. J. Immunol. 35(5): p. 1539-47.

27- Adachi, Y., et al. (2004). Characterization of beta-glucan recognition site on C-type lectin, dectin 1. Infect. Immun..72(7): p. 4159-71.

28- Yadav, M. and Schorey, JS. (2003). The betaglucan receptor dectin-1 functions together with TLR2 to mediate macrophage activation by mycobacteria . 53: 112-124.
29- Parker, L. C., L. R. Prince, and I. Sabroe. (2007). Translational minireview series on Toll-like receptors: Networks regulated byToll-like receptors mediate innate and adaptive immunity. Clin. Exp. Immunol. 147:199-207.Blood 2006;108:3168-75. 